\title{
An Applied Assessment of the Procedures and Criteria for Black Spot Determination
}

\author{
Kokkalis Alexandros $^{1}$ and Kalpakis Fanourios ${ }^{2}$ \\ ${ }^{1}$ Department of Civil Engineering, Democritus University of Thrace \\ ${ }^{2}$ Department of Civil Engineering, University of Patras \\ 1akokkal@civil.duth.gr, ${ }^{2}$ fkalpakis@gmail.com
}

\begin{abstract}
Traffic accidents are the number one worldwide cause of death among youths and one of the major causes of death for all ages. Black spots are high risk locations where road accidents have been concentrated. Herein, a literature review of black spots determination methods is conducted. Certain broad approaches are used to identify them: crash numbers, crash rates related to exposure and gravity of accidents and quantitative methods. Generally, the threshold value of a safety indicator is first determined and in a subsequent phase, it is investigated whether the value of this indicator along a road subsection significantly exceeds that predetermined value. The various approaches adopted by some key countries are also presented. Turkey is one of them and as a country presents similarities with the relevant Greek road safety reality. Then, a comparison is made between the broad approaches and the method which is being used in Turkey along a section of the national road Athens-Thessaloniki. It is concluded that to obtain balanced results, road black spots should be determined as a coupling of both a statistical method at a relevant low confidence interval (90\%) together with an accident severity index method.
\end{abstract}

Keywords: black spots, safety indicators, threshold values, traffic safety

\section{Introduction}

Road accidents are one of the major causes of death worldwide. According to World Health Organization (WHO), road accidents will globally be the ninth cause of death in 2015 and seventh in 2050; this figure shows the importance of the issue of road safety $[29,30]$. It should truly become common belief that the act of driving itself constitutes the most complex and dangerous daily action which is executed by most people. Furthermore, the socioeconomic cost of road accidents is classified by far as the most significant among all the other human activities [10]. Therefore, every action for road safety improvement should be considered as important and notable. Particularly in Greece an average of 13.000 road accidents is taken place during the last five years; the average number of deaths during this period is 1.000 and the injuries reach an average number of almost 16.400 people (Table 1) [25, 28]. Despite the overall progress in the field of road safety during the last years, Greece still own the devastating privilege of the first position in number of road accidents in European Union (in this country, the rate of deaths is 10 deaths/100.000 inhabitants, whilst in Sweden, a country-pioneer in road safety, is only 3 [27]). 
Table 1. Number of Road Accidents by Casualty Type and Number of Deaths and Injuries in Greece, [28]

\begin{tabular}{|l|l|l|l|l|l|l|l|l|}
\hline Accident & $\begin{array}{l}\text { With } \\
\text { (eaths }\end{array}$ & $\begin{array}{l}\text { With } \\
\text { serious } \\
\text { injuries }\end{array}$ & $\begin{array}{l}\text { With } \\
\text { light } \\
\text { injuries }\end{array}$ & $\begin{array}{l}\text { Total } \\
\text { accidents }\end{array}$ & $\begin{array}{l}\text { No. of } \\
\text { Deaths }\end{array}$ & $\begin{array}{l}\text { Serious } \\
\text { injured }\end{array}$ & $\begin{array}{l}\text { Light } \\
\text { injured }\end{array}$ & $\begin{array}{l}\text { Total } \\
\text { casualties }\end{array}$ \\
\hline 2000 & 1458 & 2037 & 13261 & 16756 & 2103 & 4213 & 26166 & 32482 \\
\hline 2001 & 1712 & 2512 & 15446 & 19670 & 1911 & 3251 & 22758 & 27920 \\
\hline 2002 & 1458 & 2037 & 13261 & 16756 & 1655 & 2581 & 19625 & 23861 \\
\hline 2003 & 1409 & 1824 & 12514 & 15747 & 1613 & 2345 & 18218 & 22176 \\
\hline 2004 & 1374 & 2032 & 11993 & 15399 & 1547 & 2521 & 17254 & 21322 \\
\hline 2005 & 1311 & 1861 & 13488 & 16660 & 1470 & 2327 & 19133 & 22930 \\
\hline 2006 & 1351 & 1681 & 12620 & 15652 & 1493 & 2056 & 19898 & 23447 \\
\hline 2007 & 1292 & 1462 & 11872 & 14626 & 1449 & 1812 & 18223 & 21484 \\
\hline 2008 & 1414 & 1542 & 12035 & 13577 & 1550 & 1886 & 16685 & 20121 \\
\hline 2009 & 1314 & 1389 & 12072 & 13461 & 1463 & 1669 & 16683 & 19815 \\
\hline 2010 & 1162 & 1454 & 12456 & 15072 & 1281 & 1754 & 17024 & 20059 \\
\hline 2011 & 1011 & 1395 & 11222 & 13628 & 1092 & 1672 & 15126 & 17890 \\
\hline 2012 & 899 & 1192 & 10226 & 12317 & 976 & 1443 & 13675 & 16094 \\
\hline 2013 & 802 & 1107 & 10145 & 12188 & 865 & 1315 & 13510 & 15690 \\
\hline 2014 & 747 & 895 & 10037 & 11679 & 801 & 1068 & 13216 & 15085 \\
\hline
\end{tabular}

It is well known that three parameters and their combinations, contribute to a road accident, in a variable rate: human factor, vehicle and the road infrastructure with the road environment. From these factors, road infrastructure and road environment is the second most important cause of accidents, contributing from $3 \%$ (alone) to $27 \%$ (in connection with human factor) (Figure 1, [4, 19]). Locations in which the accidents concentration (recorded number) is higher than the stochastic expected during a certain period of time, are known as black spots (also: hot spots, hazardous locations, high accident concentrations, sites with promise); this concentration is occurred for a variety of reasons connected to infrastructure problems and local risk factors and may be related to geometric design and traffic factors. In international fieldwork, there is no common unanimity about the definition and the ways of finding for black spots $[5,9,13,21]$. As a result, there is a research interest in the investigation of the outcomes which each one of the ways of determining black spots results in. According to [9], the main factors which are taken into account in order to evaluate the performance of road safety are: Average Annual Day Traffic (AADT), curvature (length and radius), tangent length, lane width, shoulder width, accesses density, roadside hazards, sight distance, road gradient, pavement condition and speed limit.

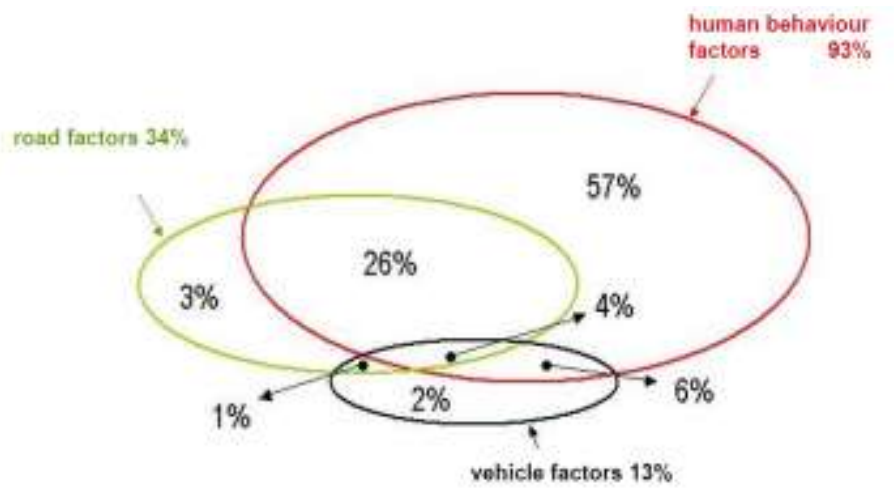

Figure 1. Road Accidents Contributing Factors [4, 19] 
In this article, the most tested and widespread methods of finding black spots are presented. Then, these methods are implemented on a road section of New National Road Athens-Thessaloniki, which administratively belongs to Regional Unit of Fthiotida in Central Greece; data are referred to a period prior to transform this section from a single carriageway to a motorway. Certain methods have been implemented as a way to determine the number of black spots and to compare the number of these spots each method results (also to find out how many and which type of black spots are common among all these methods); finally, to propose an alternative combination of different methods.

\section{Methods \& Procedures of Finding Black Spots on Road Networks}

According to Hayer [3], some investigators detect black spots towards the exposure of drivers (accidents per vehicle-kilometers), some rank them based on per-entering vehicles, some use accident frequency (accidents per year or accidents per km-year), some use accident gravity and others use a combination of the aforementioned methods. According to Geurts and Wets [13], the ranking of a road subsection as a black spot should be defined by a comparison of accident rate or accident frequency with a critical value (threshold); this value should be exceeded by the above rate or frequency for this road section, in order to be defined as a black spot. In order to take a relevant decision, quality statistical tests make up a fundamental tool. As an inextricable part of the process, in situ inspections should be taken into consideration; in these inspections all the elements which contribute in the rise of road risk should be recognized, such as faults in construction, faulty road design, lack of maintenance, inappropriate or deficient traffic signs, lack of visibility, slippery road, faulty invocation etc. Following this procedure, unitary road sections for which ways of finding black spots show as hazardous but nothing in road infrastructure suggests as dangerous, are excluded from black spots.

In short, in order to define black spots, all the following steps should be followed:

1. data collection about traffic and accidents,

2. data procession,

3. finding places with a high number of accidents by using a vigorous method,

4. accident's analysis in each one of these places and

5. in-situ inspection in these points, as referred before.

In case of finding the cause of these accidents, then these positions are named as black spots and ways of treatment in each location are proposed in order to improve road traffic safety. Finally, hazardous positions are classified and are assessed by the way and the cost of restoration, as a way to order the necessary interventions [14].

Based on bibliography, the most common and premier methods of finding black spots (hazardous places) are the following:

- crash frequency,

- random Poisson distribution,

- accident rate $\mathrm{R}$, or number,

- gravity rate (index) Gr,

- quality control,

- the empirical Bayes method and

- potential for improvement. 
In general, all the above methods should be applied in road sections with similar geometric and traffic features. Each one of the road section is divided into unitary sections with specific length. Inevitably, this elementary length constitutes a function of the accurate recording of road accidents; this length is usually around $1 \mathrm{~km}$ for interurban roads.

\subsection{Methods of Black Spots Identification}

\section{Crash frequency}

Crash frequency is the simplest hot spots identification method. A road section is divided in similar unitary length and then they are ranked in descending order of crash frequencies.

\section{Poisson distribution}

According to the random Poisson distribution, for a certain confidence level, firstly the critical number of accidents for a unitary road section is estimated; this number makes up the threshold, the overrun of which means that the number of accidents which takes place in the section of the road is not statistically random and the section is hazardous. Despite the fact that this method is statistically excellent, it doesn't take into account the traffic volume and the gravity (significance) of accidents; these elements are the main disadvantages of this method [12].

\section{Accident rates}

Accident rates could be implemented in order to define black spots. In general, accident rates are the deduction of number of accidents in relation to a specific parameter (denominator). Such parameters could be the number of vehicle-kilometers travelled (VKT), the number or cost of accidents per vehicle-kilometer or per registered vehicle, the number of inhabitants, the length of the road network or the total number of vehicles. The most common index takes into consideration the exposure in possible accident, as this is expressed by the vehicle-kilometers travelled (index R). Index R is calculated as shows in formula (1).

$$
R=\frac{Z^{*} 10^{6}}{Q^{*} L^{*} T}
$$

where:

$\mathrm{R}$ is accident rate (i.e., accidents per million VKT),

$\mathrm{Z}$ : number of accidents,

Q: yearly main traffic volume,

$\mathrm{L}$ : length of the tested section of road (in $\mathrm{km}$ ) and

T: period of time under which accidents are taken place.

In this method, there is a comparison between the number of accidents in each unitary road section and the total accident rate of the road, multiplied by a coefficient (usually 1,2 or 1,5). The main disadvantage of this method is that it doesn't take into consideration the severity of road accidents, so for this reason it receives criticism.

In general, accidents in a few defective unitary road sections could very often be serious (serious injuries or deaths), due to serious problem in road infrastructure and objective conditions (i.e., high $\mathrm{V}_{85}$ ). This fact should play an important role in the ranking of these unitary road sections as black spots; so, accident gravity should be a parameter which is being used to define these spots. 


\section{Gravity Rate}

Gravity is often determined by the financial evaluation of the road accidents consequences, which is damages, injuries and deaths. A typical formula which is used in order to calculate gravity rate shows in equation (2),

$$
G r=\frac{\left(N^{*} p_{1}+T^{*} p_{2}\right) * 10^{6}}{365^{*} Q^{*} L^{*} t}
$$

where:

$\mathrm{N}$ : number of deaths,

$\mathrm{T}$ : number of injuries, $\mathrm{p}_{1}$ and $\mathrm{p}_{2}$ gravity coefficients,

Q: main traffic volume,

$\mathrm{L}$ : length of the tested section of road (in $\mathrm{km}$ ) and

t: period of time under which road accidents are taken place.

In the numerator, the evaluation of the severity of road accidents can be represented with the intended accuracy. A gradation among deaths, serious injuries, light injuries and possible damages can be introduced; so, these parameters can be differentiated. As the description of the consequences of road accidents is more detailed, more reliable and analytical accident data are required. In Greece such detailed and reliable data are usually not provided. Whereas the above statement and based on financial features, a gravity coefficient $\mathrm{p}_{1}=45$ for deaths is typically used; respectively, the coefficient which is often used for the injuries is $p_{2}=5$. Following the estimation for gravity rate for each unitary section and the mean for the whole road sections, the threshold is estimated by multiplying the mean gravity rate with an incremental coefficient (usually 1,2 or 1,5 ). The road sections in which their gravity rate is greater than the incremental mean value for the whole road are referred as black spots. This method uses the severity of road accidents, so it gives an answer to the critical thoughts for the previous methods. However, there is a possibility a position, where a single random event of a serious road accident, with a certain number of deaths, has been occurred, to be named as hazardous. Hence, the objective dangerousness (i.e., road features) should be taken into account as well.

\section{Quality Control}

A very common method which is used to determine hazardous road positions is named quality control. In this method for each road section with same traffic volume and geometric features, the mean of accidents per kilometer is calculated. Afterwards, based on table of the Poisson probabilities, the lowest level for a certain confidence interval (i.e., 95\%) is found; after that, the critical rate of accident is calculated (3),

$$
R_{i}=R_{a}+k * \sqrt{\frac{R_{a}}{M}+\frac{1}{2 M}}
$$

where:

$\mathrm{R}_{\mathrm{i}}$ is the critical accident rate (i.e., accidents per million VKT),

$\mathrm{R}_{\mathrm{a}}$ : mean average accident rate for all the road sections with similar features,

$\mathrm{K}$ : probabilistic parameter set by the desirable statistical confidence interval for $\mathrm{R}_{\mathrm{i}}$ and M: number of vehicle-kilometers.

In this method, also, if the number of accident on a road section is equal to or higher than the critical rate, then this is not considered a random incident, but is due to the objective infrastructure hazardousness. Severity of the accidents isn't taken into account in the quality control method, too.

\section{The empirical Bayes}

The empirical Bayes approach to road safety $[6,17]$ makes it possible to provide unbiased estimates of the expected number of accidents for individual elements of the 
road system. This is attained by combining the recorded number of accidents with the model estimate for that site. In Bayesian statistics anything about which is uncertain, including the true value of a parameter (such as the true accident frequency at a location), can be thought of as being a random variable to which we can assign a probability distribution, whilst, in frequent statistics, critical parameters are fixed quantities. The difference to other methods is that Bayes approach has the aspiration to identify hazardous road locations that have an abnormally high expected number of accidents and not just a recorded one, which may attributed to data randomness. Furthermore, the Bayes approach, through before-and-after studies, can offer evaluation of black spot treatment.

More specifically, Bayes model parameters are expressed by placing a probability distribution (most commonly a negative binominal regression model) on the parameters, called the prior distribution $(p(\theta))$, that represents additional information that is available; and the dependent variable is expressed in the "likelihood," which is proportional to the distribution of the observed data given the model parameters, written as $p(y \mid \theta)$. All Bayesian inference is based on the posterior distribution, which is produced by a combination of $(\theta)$ and $p(y \mid \theta)$. In Bayes' theorem, the posterior is proportional to the prior times the likelihood, or more precisely:

$P(y \mid \theta)=\frac{p(y \mid \theta) * p(\theta)}{\int p(\theta) * p(y \mid \theta) d x}$

It is commented that the empirical Bayes approach is not widely applied in Europe, as much as in North America [2].

\section{Potential for Improvement}

Rather than using overall accident frequencies at sites, what is really of importance is the potential of accident reduction [1,7]. These methods rest on the premise that only 'excess' accidents over those expected from sites with similarities can be prevented by applying appropriate treatments. The potential for improvement is the difference between the recorded number of accidents and that predicted by models like Poisson or empirical Bayes. When the potential for improvement is greater than zero, the site experiences more crashes than expected and this may be worth improving.

\section{Evaluation}

From all the above statements, it can be deducted, that the number of black spots would depend on the method which a researcher/an agency follows: different number and hazardous places would result by different methods. Methodology of black spots identification varies from simple to complex and sophisticated combination of methods, whilst simplicity would always be an advantage. To evaluate these methods, certain quantitative criteria [1,7] have been proposed, like the site consistency test, measuring the ability of a method to identify high-risk sites over different observation periods, the method consistency test, evaluating the repeatability of the results, the total rank difference, taking into account the safety rankings of various road sections during two time periods and the false identification test, where the actual hot spots are known and the methods are evaluated against how few false identifications predict. The simple accident rate method performs better on site consistency test as well as predicts fewer false identifications. The rather complicated empirical Bayes method outperforms in the rest two tests and ranked second in the others, thus being the most consistent and reliable one for hot spots identification. However, a road section causing fewer traffic accidents but with consistent serious casualties may be missed, unless the gravity of the accidents taken into consideration. A typical hazardous site definition may be that where the observed number of accidents exceeds either the accident prediction Poisson model estimate or the empirical model estimate by at least one standard deviation. By that definition, the 
empirical Bayes estimate yields fewer hot spots than Poisson model [8]. Also, a real supremacy of the Bayes method occurs where sample sizes are small [17].

\subsection{Criteria for Black Spots Identification in Various Countries}

National traffic safety Agencies prefer to propose, instead, a clear set of criteria and definitions to detect hazardous road locations. A great variety is also identified in these approaches. Even in the simplest but crucial parameter of road subsection unit length, one can meet a variety of definitions, from $100 \mathrm{~m}$ to $1 \mathrm{~km}$. It is of research interest to present and summarize in a Table the different methods followed by certain countries.

\section{Australia}

In Australia, there is no universally common definition for black spots; sites are nominated as black spots after an assessment of the level of risk and the likelihood of a crash occurring at each site. Each State follows different programs to nominate a black spot area (Table 2, [23]).

Table 2. Fundamental Black Spot Identification Criteria in Australia

\begin{tabular}{|c|c|c|c|c|c|c|c|}
\hline \multirow{3}{*}{$\begin{array}{c}\text { County } \\
\text { Crash criteria } \\
\text { for intersection } \\
\text { or mid-block or } \\
\text { short road } \\
\text { section (length } \\
<3 \mathrm{Km})\end{array}$} & \multicolumn{4}{|c|}{ Western Australia Black spot program } & \multirow{3}{*}{$\begin{array}{c}\text { Federal } \\
\text { Black Spot } \\
\text { Program } \\
\\
3 \text { casualty } \\
\text { crashes over } \\
\text { a 5-year } \\
\text { period }\end{array}$} & \multirow{3}{*}{$\begin{array}{c}\text { South } \\
\text { Australia } \\
\text { Black Spot } \\
\text { Program } \\
\\
3 \text { casualty } \\
\text { crashes over } \\
\text { a 5-year } \\
\text { period }\end{array}$} & \multirow{3}{*}{$\begin{array}{c}\text { Tasmania } \\
\text { Black Spot } \\
\text { Program } \\
\\
3 \text { casualty } \\
\text { crashes over a } \\
\text { 5-year period }\end{array}$} \\
\hline & $\begin{array}{l}\text { State } \\
\text { metro } \\
\text { roads }\end{array}$ & $\begin{array}{l}\text { State } \\
\text { rural } \\
\text { roads }\end{array}$ & $\begin{array}{l}\text { Local } \\
\text { metro } \\
\text { roads }\end{array}$ & $\begin{array}{l}\text { Local } \\
\text { rural } \\
\text { roads }\end{array}$ & & & \\
\hline & $\begin{array}{c}10 \\
\text { crashes } \\
\text { over } 5 \\
\text { years }\end{array}$ & $\begin{array}{c}3 \\
\text { crashes } \\
\text { over } 5 \\
\text { years }\end{array}$ & $\begin{array}{c}5 \\
\text { crashes } \\
\text { over } 5 \\
\text { years }\end{array}$ & $\begin{array}{l}3 \text { crashes } \\
\text { over } 5 \\
\text { years }\end{array}$ & & & \\
\hline $\begin{array}{l}\text { Crash criteria } \\
\text { for road length } \\
\quad(\geq 3 \mathrm{Km})\end{array}$ & $\begin{array}{l}\text { Average } \\
\text { of } 3 \\
\text { crashes } \\
/ \mathrm{km} \text { over } \\
5 \text { years }\end{array}$ & $\begin{array}{l}\text { Averag } \\
\text { e of } 1 \\
\text { crash } \\
/ \mathrm{km} \\
\text { over } 5 \\
\text { years }\end{array}$ & $\begin{array}{c}\text { Averag } \\
\text { e of } 2 \\
\text { crashes } \\
/ \mathrm{km} \\
\text { over } 5 \\
\text { years }\end{array}$ & $\begin{array}{c}\text { Average } \\
\text { of } 1 \\
\text { crash } \\
/ \mathrm{km} \text { over } \\
5 \text { years }\end{array}$ & $\begin{array}{l}\text { Average of } \\
0,2 \text { crashes } \\
/ \mathrm{km} / \text { year } \\
\text { over } 5 \text { years } \\
\text { or top } 10 \% \\
\text { of sites } \\
\text { having the } \\
\text { highest crash } \\
\text { rate / region }\end{array}$ & $\begin{array}{l}\text { Average of } \\
0,2 \text { crashes } \\
/ \mathrm{km} / \text { year } \\
\text { over } 5 \text { years } \\
\text { or top } 10 \% \\
\text { of sites } \\
\text { having the } \\
\text { highest crash } \\
\text { rate / region }\end{array}$ & $\begin{array}{c}\text { At least } 1 \\
\text { reported } \\
\text { crash/km } \\
\text { within } 5 \text { years }\end{array}$ \\
\hline $\begin{array}{c}\text { Benefit/Cost } \\
\text { Ratio }\end{array}$ & \multicolumn{4}{|c|}{$\geq 1$} & $\geq 2$ & $\geq 1$ & Not stated \\
\hline
\end{tabular}

\section{Austria}

According to [14], scenes of accidents are distinguished in black spots and hazardous locations, depending on their recorded crash history. A hazardous location is classified as a black spot, if one of the following two criteria has to be met:

1. Three or more similar injury accidents within 3 years and a relative coefficient $A$ of at least 0,8 . The value of this coefficient is calculated as follows (5),

$$
A=\frac{U}{0,5+7 * 10^{-5} * A A D T}
$$

where:

AADT is the Annual Average Daily Traffic and $U$ the number of injury accidents within 3 years. 
2. At least 5 accidents (including property damage only) of similar type within a year.

For the above purpose, a sliding window with a length of $250 \mathrm{~m}$ is being used.

The critical value of 0.8 of the relative coefficient A will be reached for example if there are 3 injury accidents in 3 years and the AADT is up to 10,700 vehicles/24 hours or 4 injury accidents in 3 years and the AADT is up to 16,700 vehicles/24 hours etc.

\section{Croatia}

In Croatia, as happens in many other countries, a unique methodology to determine black spots is not being developed; in this country, black spots are identified based on the ranking of the number of traffic accidents on specific location. [26]. This method does not take into account all relevant parameters nor a systematic identification characteristics of black spots. There are some criteria only for roads which are supervised by the authority of the Croatian Roads. In these roads, black spot is an intersection or a road segment 300 $\mathrm{m}$ length or part of a road length of 300 to $1000 \mathrm{~m}$, satisfying one of the following criteria:

- 12 or more accidents with injuring in the past 3 years,

- 15 or more recorded accidents regardless to consequences during a 3-year period,

- 3 or more identical accidents, with the same group of participants, same moving direction and same conflict area.

\section{Denmark}

In Denmark the definition of black spots relies on a detailed classification of the road system into different types of road sections (motorways, other dual carriageways in urban/interurban environment) and various types of intersections. In this country, data refers to a period between 3 and 5 years, and Poisson distribution is used in order to define black spots (confidence interval is 95\%). The AADT volume is the major factor in order to calculate the normal expected number of accidents. In Denmark, black spot is a site with a reported number of accident which is higher than both a fixed minimum number ( 4 accidents during a five-year period) and much higher than the normal expected number of accidents for a similar type of roadway element.

\section{Flanders}

In this region of Belgium, hazardous segment is called a road section maximum length of $100 \mathrm{~m}$ where there are observed at least 3 accidents during a three-year period. These segments are called as black spots if their severity index (S) is greater than (or equal to) a fixed number (i.e., 15), for a three-year period. This index is calculated as shown in equation (6),

$\mathrm{S}=\mathrm{LI}+3 * \mathrm{SI}+5 * \mathrm{DI}$

where:

LI is the total number of slightly injured,

SI the total number for serious injured and

DI the number of deaths for this three-year period.

\section{Germany}

In Germany, there is a definition of black spots, black sections and black areas (the last one mainly refer to urban areas); these positions are defined by a comparison between the number of accidents on them and critical thresholds, depending on the period of time $(1,2$ or 3 years usually). There is an identification of spots with similar types of accidents and similar level of accident severity (fatal, serious injured, lighter injured, serious material damage, other damage), Severity is taken into account in defining black spots by reducing the critical values in serious injured accidents and injury accidents. 


\section{Hungary}

In this country, there is a distinction between urban and interurban areas: the unit road section should be no longer than $1 \mathrm{~km}$ for outside built-up areas and no longer than 100 meters in inside-built areas. Black spots are sites where at least 4 accidents are recorded during a period of 3 years. Traffic volume is taken into account in the ranking of black spots.

\section{Malaysia}

According to Royal Malaysia Police [23], black spots are sites where more than 5 accidents are taken place within $50 \mathrm{~m}$ radius over 3 consecutive years or more than 3 accidents of the same time within 30m radius over 3 consecutive years. However, according to the Malaysian Public Works Department, hot spots are sites with 9 or more injury accidents within $50 \mathrm{~m}$ of a junction (or on $200 \mathrm{~m}$ on a road section) over the past 3 years. An accident point weighting system was adopted by the Malaysian Highway Planning Unit; in this system the following ratio is being used for the accidents: fatals/serious injuries/slight injuries/damages only 6/3/0,8/0,2 [23].

\section{New Zealand}

In New Zealand, a threshold of 3-5 accidents over 5 years has been suggested.

\section{Norway}

In this country there is a separation between black spots and black sections. A black spot is defined as a section of road with a maximum length of $100 \mathrm{~m}$, in which at least 4 injury accidents are occurred during the last 5 years and black section is a road section with a maximum length of $1 \mathrm{~km}$, where at least 10 injury accidents are recorded during the last 5 years. Hazardous spots and hazardous sections are identified by applying a sliding window. Hazardous sections are often consist of several hazardous spots which are located near one another.

\section{Poland}

In Poland as a black spot section is treated a road section $1 \mathrm{~km}$ in length or less on which during the last 5 years has taken place 12 or more accidents.

\section{Portugal}

In Portugal, there are two ways of defining black spots. In the first one, black spots are the road sections with maximum length of $200 \mathrm{~m}$, where at least 5 or more accidents are taken place; in addition to this, the severity index should be greater a fixed value (20), in the period of analysis. This severity index is calculated as shows in equation (7),

$$
\mathrm{SI}=1 * \mathrm{LI}+10 * \mathrm{SI}+100 * \mathrm{~F}
$$

where:

LI the number of slight injured,

SI the number of serious injured and

$F$ the number of fatalities.

In the second method, a hazardous location is a geographical area where the expected accident frequency is higher than in similar areas, because of the road characteristics. In the second approach, there is a differentiation between intersection and non-intersection places. In the first case, the minimum length should be $250 \mathrm{~m}$ for single carriageway roads and $500 \mathrm{~m}$ for dual carriageway roads; furthermore, road network is classified in 6 classes and in each class a different unique accident prediction model is fitted. In these models, the most significant variable is AADT. 


\section{Switzerland}

In Switzerland, a black spot is called a road subsection where the number of accident is significantly higher than the number of accident in comparable sites. There is a certain procedure in order to find these comparable sites individual for road subsections and intersections. The length of a subsection varies according to the type of road (between 100 $\mathrm{m}$ and $500 \mathrm{~m}$, depending on the importance of the road). Accident sites are those where the number of accidents exceeds the estimated expected number of accidents based on normal accident rates. These sites are compared to threshold values in order to find out whether they are black spots or not. The threshold values vary, depending on the road type, and they refer to a period of 2 years.

\section{United Kingdom}

In Scotland, black spot is a position where 3 or more casualty accidents are taken place within 3 years in a $100 \mathrm{~m}$ radius. In England these criteria are set by local authorities.

\section{United States (certain States)}

In United States there is not a common approach of the issue. In Kentucky, for instance, the minimum number of crashes is 14 over 3 years in urban areas and 5 crashes over 3 years in interurban areas. The critical risk factor is calculated by dividing the actual crash rate by the average statewide crash rate for the particular type of road or intersection; this factor should be clearly greater than 1 in order to nominate a black spot. In Colorado, the weighted hazard index should be equal or greater than zero; in this index crash frequency, severity, traffic volume and statewide weighted crash average for the particular class of road or intersection are taken into account. The fundamental criteria in this state is 7 damage only or casualty crashes or 3 fatal accidents over three years [16].

\section{Turkey}

Turkey has been intentionally left as the last country, outside the above alphabetical presentation. In this country, the quality control method is used [20], together with three parameters, for each unitary road section with a length of $1 \mathrm{~km}$. This statistical method is called rate-quality-control method and uses the three following indexes in order to determine black spots: 1) accident rate, 2) accident frequency and 3) severity index; each one of these indexes is compared to critical values. Black spot is a section where all these three indexes are higher than the critical values for each one respectively. In Turkey, the number of deaths per 100.000 inhabitants is comparable to Greece [19]. For this distinctiveness, Turkey approach is presented in more details.

The first index, which is accident rate, a ratio $R_{j}$ is defined as shown in equation (8),

$$
R_{j}=\frac{A_{j}}{m_{j}}
$$

where:

$\mathrm{Aj}$ is the number of accidents on section $\mathrm{j}$ during a certain period of time and $\mathrm{m}_{\mathrm{j}}$ is the number of vehicle-kilometers (in millions), on this section $\mathrm{j}$ during the same period of time

$R_{c}$ is a threshold (critical value) for the accident rate, which is defined as follows (9),

$$
R_{c}=\hat{\lambda}+k_{a} \sqrt{\frac{\hat{\lambda}}{m_{j}}}-\frac{0,5}{m_{j}}
$$


where:

$$
\hat{\lambda}=\frac{\sum_{i=1}^{n} A_{i}}{\sum_{i=1}^{n} m_{i}}=\frac{1}{n} \sum_{i=1}^{n} \frac{m_{i}}{\bar{m}} R_{i}
$$

In these equations, $\lambda$ is the estimated average accident rate for section belonging to the same population, and $\mathrm{k}_{\mathrm{a}}$ is a constant the choice of which is based on statistical significance check. This constant is selected by the normal distribution and can take the following values:

-for significance level $\mathrm{a}=0,1 \%, \mathrm{k}_{\mathrm{a}}=2,576$

-for significance level $a=5 \%, k_{a}=1,645$

-for significance level $\mathrm{a}=10 \%, \mathrm{k}_{\mathrm{a}}=1,282$

In the accident frequency method, a section is defined as black spot only if the accident frequency $A_{j}$ of this section is greater than a threshold $A_{c}$ (expressed in number of accidents). The value of this threshold is defined as shown in (11),

$$
A_{c}=F_{\text {ave }}+K_{a} * \sqrt{\frac{F_{a v e}}{L_{j}}}-\frac{0,5}{L_{j}}
$$

where:

$\mathrm{L}_{\mathrm{j}}$ is the length of the road sections,

$F_{a v e}$ is the average accident frequency for the whole road (for all road sections).

A position can be a black spot if accident frequency $A_{j}$ is greater than (or at least equal to) the threshold $\mathrm{A}_{\mathrm{c}}$.

In the third method, the gravity index, a relative gravity $3: 1$ between deaths and injuries, as well as between injuries and damaged vehicles is used. The severity is calculated as in (12),

Severity $S_{\mathrm{j}}=9 * I_{\mathrm{f}, \mathrm{I}}+3 * \mathrm{I}_{\mathrm{b}, \mathrm{j}}+1 * \mathrm{I}_{\mathrm{d}, \mathrm{j}}$

where:

$\mathrm{I}_{\mathrm{f}, \mathrm{I}}$ : number of fatals,

$\mathrm{I}_{\mathrm{b}, \mathrm{j}}$ number of injured and

$I_{d, j}$ is the number of damaged vehicles.

After that, the following quotient is calculated (13a), as well as the variance (13b),

$$
\begin{gathered}
Q_{\text {ave }}=\frac{\sum_{i=1}^{n} S_{i}}{\sum_{i=1}^{n} A_{i}} \\
\hat{\sigma}^{2}=\frac{1}{n-1} \sum_{i=1}^{n}\left(Q_{i}-Q_{a v e}\right)^{2}
\end{gathered}
$$

A road site is considered to be a black spot, if the following condition $\mathrm{Q}_{\mathrm{j}}>\mathrm{Q}_{\mathrm{c}}$ is valid. The threshold $\mathrm{Q}_{\mathrm{c}}$ is calculated as in (14),

$$
Q_{c}=Q_{\text {ave }}+K_{a} * \sqrt{\hat{\sigma}^{2}}-0,5
$$

the variables are as previously defined.

It is noteworthy the relative low gravity for the fatal accidents which is used in this method. In addition to this, the complexity of this method should also be noticed. Furthermore, due to lack of data about the number of damaged vehicles in road accidents, 
the factor $I_{d, j}$ is difficult to be estimated (there are accidents with only damages for example which are not systematically recorded by police agencies).

\section{Commenting}

In the following Table 3 the European approaches to black spot definition are outlined and compared. Many variations are obvious, most distinct one, the simplest one, that of road unit length, which greatly affects accident threshold values. It seems that along interurban roads a $0,5 \mathrm{~km}$ unitary road length should be adopted. A 3 year analysis period seems long enough for hot spots identification. As far as the actual accident threshold, this should depend on the road type and on the traffic safety level of the country as well. It also worth's commenting a tendency to simplicity and the complete absence of more complicated yet more precise methods, like the empirical Bayes.

\section{Implementation of Methods and Criteria for Black Spot Detection}

For research purposes, the most widespread method for black spots identification are applied to a Greek national road section with high traffic volumes and high accident rates. This road section has recently been upgraded from a single carriageway to a dual 2-lane motorway. This is considered as an advantage, both from the road safety point of view, (due to the sharp decrease of accident risk) and having less legal and administrative complications.

The data were collected by the police agency of the Regional Unit of Fhtiotida [11, 15]; these data referred to a road section with a total length of $144 \mathrm{~km}$. This section is divided into two sub-sections; the first one is a section with a length of $65 \mathrm{Km}$ between the positions $117+000 \mathrm{Km}$ and $181+000 \mathrm{Km}$ and the second one between the positions $182+000 \mathrm{~km}$ and $260+000 \mathrm{~km}$ (Figure 2). In these subsections, the number of accidents are referred to a different timebase; in the first one the time base is 5 years (time period from 2007 to 2011) and in the second one 7 years (time period from 2005 to 2011), (Table 4). In Table 5, the road risk of these subsections is shown, as well as, the critical thresholds of the accident rates and their gravity rates.

Table 3. Overview of European Procedures \& Criteria to Identify Black Spots

\begin{tabular}{|c|c|c|c|c|c|}
\hline Country & $\begin{array}{l}\text { Reference to } \\
\text { method }\end{array}$ & $\begin{array}{l}\text { Sliding } \\
\text { window } \\
\text { applied }\end{array}$ & $\begin{array}{l}\text { Minimum } \\
\text { number of } \\
\text { accidents }\end{array}$ & $\begin{array}{l}\text { Accident } \\
\text { severity } \\
\text { considered }\end{array}$ & $\begin{array}{c}\text { Length of } \\
\text { identification } \\
\text { period }\end{array}$ \\
\hline Austria & $\begin{array}{c}\text { Accident rate, } \\
\text { formula }(5)\end{array}$ & $250 \mathrm{~m}$ & $\begin{array}{c}3 \text { injuries } \\
\text { or } \\
\text { any } 5 \\
\end{array}$ & Yes & 3 years \\
\hline Croatia & $\begin{array}{l}\text { Road sections } \\
\text { ranking }\end{array}$ & $\begin{array}{c}300-1000 \\
\mathrm{~m}\end{array}$ & $\begin{array}{c}12 \text { injuries or } \\
\text { any } 15 \text { or } \\
3 \text { identical }\end{array}$ & Yes & 2 years \\
\hline Denmark & Poisson & $\begin{array}{l}\text { variable } \\
\text { length }\end{array}$ & 4 & No & 5 years \\
\hline $\begin{array}{l}\text { Flanders } \\
\text { (Belgium) }\end{array}$ & $\begin{array}{l}\text { Gravity rate, } \\
\text { formula (6) }\end{array}$ & $100 \mathrm{~m}$ & $\begin{array}{c}3 \text { and } \\
\text { gravity > } 15\end{array}$ & Yes & 3 years \\
\hline Germany & $\begin{array}{l}\text { Gravity } \\
\text { indexes }\end{array}$ & $\begin{array}{l}\text { accident } \\
\text { maps }\end{array}$ & 3 or 5 & $\begin{array}{c}\text { Yes, by } \\
\text { different } \\
\text { critical values }\end{array}$ & $\begin{array}{c}1 \text { year (all } \\
\text { accidents) }-3 \\
\text { years (injuries) }\end{array}$ \\
\hline Hungary & Accident rate & $\begin{array}{l}1 \mathrm{~km} \text {, } \\
\text { urban: } \\
100 \mathrm{~m}\end{array}$ & 4 & No & 3 years \\
\hline
\end{tabular}




\begin{tabular}{|c|c|c|c|c|c|}
\hline Norway & $\begin{array}{c}\text { Statistical } \\
\text { test, Poisson }\end{array}$ & $\begin{array}{c}100 \mathrm{~m} \\
\text { (spot) or } \\
1 \mathrm{~km} \\
\text { (section) }\end{array}$ & $\begin{array}{c}\text { higher than } \\
\text { normal } \\
4 \text { (spots) or } \\
10 \text { (sections) }\end{array}$ & $\begin{array}{c}\text { via accident } \\
\text { costs and } \\
\text { potential } \\
\text { savings }\end{array}$ & 5 years \\
\hline Poland & No & $1 \mathrm{~km}$ & 12 & No & 5 years \\
\hline Portugal & $\begin{array}{c}\text { Gravity rate, } \\
\text { formula (7) }\end{array}$ & $200 \mathrm{~m}$ & 5 & Yes & 5 years \\
\hline Scotland & No & 200 & 3 & No & 3 years \\
\hline Switzerland & Accident rate & $\begin{array}{c}100-500 \\
\mathrm{~m}\end{array}$ & $\begin{array}{c}\text { set of critical } \\
\text { values }\end{array}$ & $\begin{array}{c}\text { Yes, by } \\
\text { different } \\
\text { critical } \\
\text { values }\end{array}$ & 2 years \\
\hline
\end{tabular}

Table 4. Basic Data for the Subsections of New National Road AthensThessaloniki

\begin{tabular}{|c|c|c|c|c|c|}
\hline $\begin{array}{c}\text { Section of } \\
\text { PATHE }(\mathrm{Km} \\
\text { place })\end{array}$ & $\begin{array}{c}\text { Length } \\
(\mathrm{Km})\end{array}$ & $\begin{array}{c}\text { Yearly } \\
\text { Mean } \\
\text { Traffic } \\
\text { Volume }\end{array}$ & $\begin{array}{l}\text { Period of } \\
\text { time }\end{array}$ & $\begin{array}{c}\text { Number } \\
\text { of } \\
\text { accidents }\end{array}$ & Direction \\
\hline \multirow{2}{*}{$117-181$} & \multirow{2}{*}{65} & \multirow{2}{*}{30.000} & \multirow{2}{*}{$\begin{array}{l}2005- \\
2007\end{array}$} & 150 & Athens \\
\hline & & & & 152 & Thessaloniki \\
\hline \multirow{2}{*}{$182-260$} & \multirow{2}{*}{79} & \multirow{2}{*}{25.000} & \multirow{2}{*}{$\begin{array}{l}2005- \\
2011\end{array}$} & 416 & Athens \\
\hline & & & & 442 & Thessaloniki \\
\hline
\end{tabular}

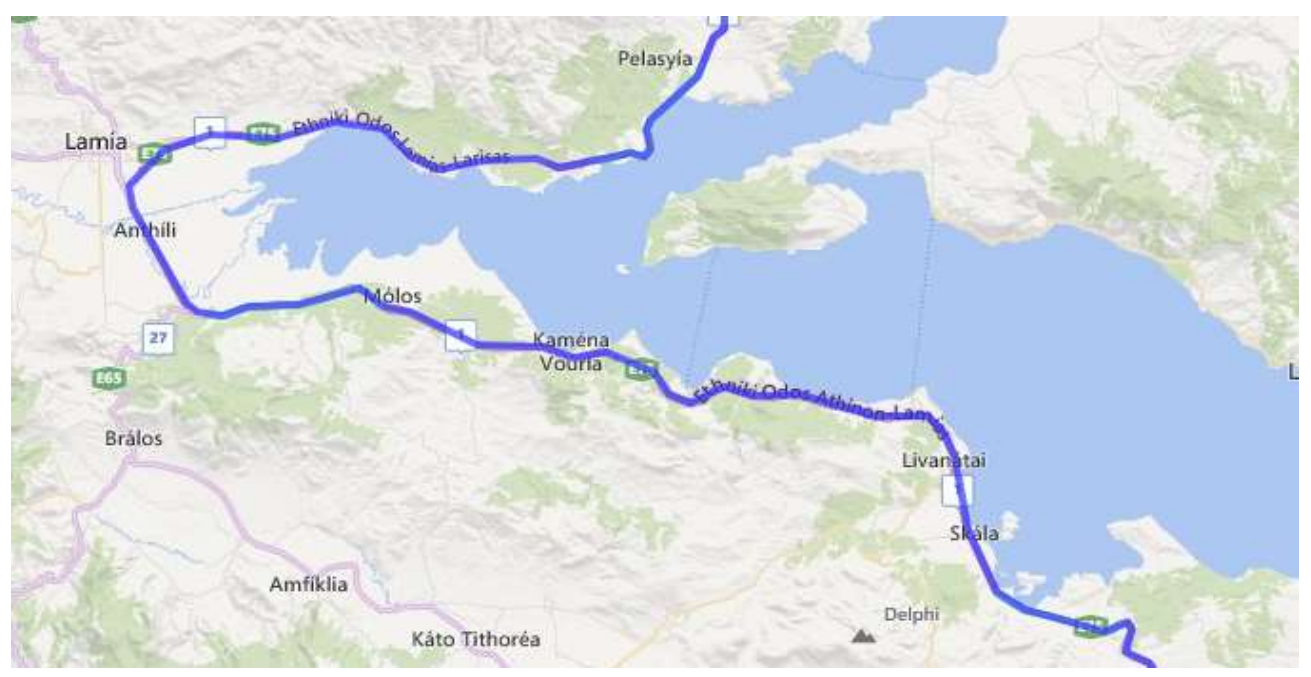

Figure 2. Section of New National Road Athens-Thessaloniki

Table 5. Number of Injuries and Rates for each One of these Subsections

\begin{tabular}{|c|c|c|c|c|c|c|c|}
\hline 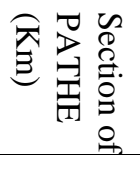 & 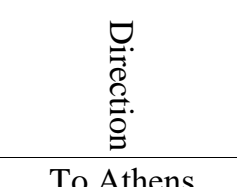 & 入气 & 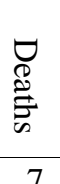 & $\underset{\substack{\Xi \\
\Xi}}{\stackrel{\Xi}{\Xi}}$ & 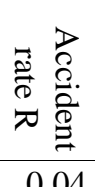 & 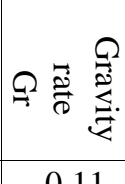 & 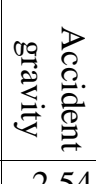 \\
\hline $117-181$ & $\begin{array}{c}10 \text { Athens } \\
\text { To Thessaloniki }\end{array}$ & $\frac{2,31}{2,34}$ & $\begin{array}{l}1 \\
8\end{array}$ & $\frac{16}{27}$ & $\begin{array}{l}0,04 \\
0,04\end{array}$ & $\begin{array}{l}0,11 \\
0,13\end{array}$ & $\begin{array}{l}2,54 \\
3,15\end{array}$ \\
\hline \multirow{2}{*}{$182-260$} & To Athens & 5,27 & 13 & 73 & 0,08 & 0,18 & 2,22 \\
\hline & To Thessaloniki & 5,59 & 18 & 73 & 0,09 & 0,23 & 2,58 \\
\hline
\end{tabular}


The results which come from the implementation of the above methods are outlined in Table 6.

Table 6. Number of Black Spots Identified by each Implemented Method

\begin{tabular}{|c|c|c|c|c|c|c|c|c|c|}
\hline \multirow[b]{2}{*}{$\begin{array}{c}\text { Section of } \\
\text { PATHE } \\
(\mathrm{Km})\end{array}$} & \multirow[b]{2}{*}{ Direction } & \multirow[b]{2}{*}{$\begin{array}{l}\bar{\nabla} \\
\tilde{\tilde{\sigma}} \\
\bar{\nabla}\end{array}$} & \multirow[b]{2}{*}{ 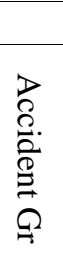 } & \multirow[b]{2}{*}{ 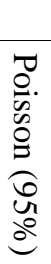 } & \multirow[b]{2}{*}{ 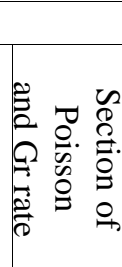 } & \multicolumn{4}{|c|}{ Versions applied in Turkey } \\
\hline & & & & & & 总. & 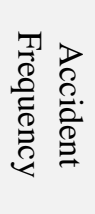 & 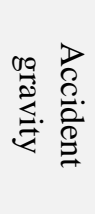 & 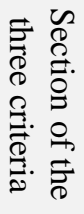 \\
\hline \multirow{2}{*}{$117-181$} & To Athens & 16 & 10 & 9 & 5 & 15 & 14 & 6 & 3 \\
\hline & To Thessaloniki & 21 & 12 & 6 & 3 & 16 & 14 & 5 & 1 \\
\hline \multirow{2}{*}{$182-260$} & To Athens & 20 & 12 & 9 & 7 & 12 & 10 & 6 & 4 \\
\hline & To Thessaloniki & 24 & 13 & 9 & 8 & 16 & 14 & 8 & 5 \\
\hline
\end{tabular}

Specifically, in Table 6 the number of black spots estimated by three major methods is presented (accident rate, accident gravity rate and Poisson distribution); for all these methods, the level of significance which is used was $a=0,05$ (confidence interval 95\%). Apart from that, the number of black spots which are resulted by the section between Poisson distribution and accident gravity rate also shown (the confidence interval is still 95\%). Also, an implementation of the method used in Turkey, in this section of the National Road Athens-Thessaloniki is comparatively presented. Differentiations are observed among similar methods, which are attributed to changes in probabilistic factors and gravity factors; the conclusion is that any change in probabilistic and gravity factors can result in markedly different outcomes (different number of hot spots). In the last column, the results from the section of all the three indexes (accident rate, accident frequency rate and accident gravity rate) are shown (as Turkey method requires). This last column operates as a powerful filter, significantly reducing the number of black spots. In Turkey, the number of blackspots is diminished by using a complex and erudite approach.

In Table 7 the number of black spots identified by criteria set in certain European countries are compared against those identified by major methods previously described. Available data refer to $1 \mathrm{~km}$ unitary road length and are, in general, impossible to be reduced to shorter subsections, hence only those country's practices at Table 3 , refer to 1 $\mathrm{km}$ unitary road section can be used.

Table 7. Number of Black Spots Identified by Typical Methods versus Criteria Set in Certain European Countries

\begin{tabular}{|c|c|c|c|c|c|c|c|c|c|c|}
\hline \multirow[b]{2}{*}{$\begin{array}{c}\text { Section } \\
\text { of } \\
\text { PATHE } \\
(\mathrm{Km})\end{array}$} & \multirow[b]{2}{*}{ Direction } & \multicolumn{4}{|c|}{ Method } & \multicolumn{5}{|c|}{ Method/criteria applied in Europe } \\
\hline & & $\begin{array}{l}\bar{\nabla} \\
\overrightarrow{\widetilde{\sigma}} \\
\bar{D}\end{array}$ & 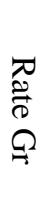 & 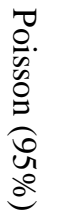 & 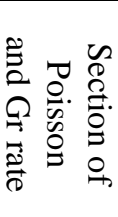 & 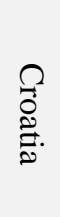 & 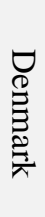 & 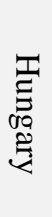 & 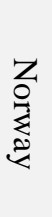 & $\begin{array}{l}\overrightarrow{0} \\
\frac{0}{\tilde{O}} \\
\text { Oे }\end{array}$ \\
\hline \multirow{2}{*}{$117-181$} & To Athens & 16 & 10 & 9 & 5 & 0 & 8 & 6 & 2 & 1 \\
\hline & To Thessaloniki & 21 & 12 & 6 & 3 & 0 & 6 & 4 & 2 & 1 \\
\hline \multirow{2}{*}{$182-260$} & To Athens & 20 & 12 & 9 & 7 & 0 & 8 & 7 & 3 & 2 \\
\hline & To Thessaloniki & 24 & 13 & 9 & 8 & 1 & 10 & 8 & 4 & 2 \\
\hline
\end{tabular}

The great diversion of the results is obvious. Croatia set very strict criteria (combination of high number of accidents with a short reference period). Poland's criteria are also strict and filter out most potentially dangerous road sections. Hungary's black 
spot identification procedure is both simple and yields results quite near to the section between Poisson distribution (with 95\% confidence interval) with accident gravity rate.

\section{Conclusions}

The identification and ranking of hazardous locations is very important towards being able to apply priority treatment, given limited budget. In the analysis preceded, the obvious conclusion that emerged is that the number of black spots constitutes a function of the followed methodology or set criteria. However, the differences which were found, have quite an important extent and that was a surprise. Generally, any change in probabilistic and gravity factors can result in different number of black spots. This magnitude of the above differentiations (sensitivity) is attributed to two reasons.

The first one refers to the different philosophy of the methods for locating black spots, either probabilistic, or taking into account mainly the accident gravity rate. The probabilistic theory is fundamentally more correct, so the gravity of accidents should be taken into account in order to reduce and rationalize the differentiations, but not in that extent that a single serious accident (with fatalities) can make a point hot by itself.

The second reason pertains to the different level of uncertainty that we accept, for a road section to be defined as hazardous. Probably for this reason, specific numbers are defined as thresholds in several countries (if these thresholds are exceeded, the unitary road section can be considered as hot), instead of a statistical overview of every similar road axis which would result in different critical values for each road section.

The answer to the first topic is probably based on the differentiation of the gravity consideration of road accidents. Gravity should be emerged, not from the grade of the social and financial consequences of each incident (evaluation of deaths, injuries and vehicle damages), but through a much milder gradation of the severity of accidents. The sense which is applied in Turkey's methods, whereas in the first approach it seems to underestimate the value of human life, finally responds to attribute a suitable coefficient on accidents gravity, but not so decisive, that even only one fatal accident can define a black spot.

The answer to the second concern could be coped reversely: in a road section, such as for example the examined ones, of 60 and $80 \mathrm{~km}$ of length, which number of black spots is considered normal and manageable? The fact that 20 or even 24 (for one direction only) road points to be considered as black spots from a sole applied method, isn't it an exaggeration? Such a pragmatistic approach of black spots identification issue, would define, in an axis coarsely and depending on the overall riskiness and the Regional available budget, a target-number for the necessary spots to be treated; on these frame, the confident intervals of the analysis could be, in a rationalized way, properly adjusted.

It seems to be that a balanced approach yields as a conjunction between the clearly probabilistic methods and the methods in which gravity of accidents is taken into account. Thus, all fundamental parameters of influence could be evaluated.

If, finally, black spots are resulted from a cross-section between, for example, the Poisson distribution (or quality control) having a lower confident interval (like 90\%) and accident gravity rate (with low gravity factors), then a manageable number of reliable defined black spots seems to be emerged.

\section{References}

[1] C. Wen and S. Washington, "New Criteria for Evaluating Methods of Identifying Hot Spots", TRB, Journal of TRR No 2083, Washington DC, (2008), pp. 76-85.

[2] R. Elvik, "A survey of operational definitions of hazardous road locations in some European countries", Accident Analysis and Prevention, vol. 40, (2008), pp. 1830-1835.

[3] E. Hauer, "Identification of sites with promise", Transportation Research Record, vol. 1542, (1996), pp. 54-60. 
[4] A. Ishtiaque, "Road Infrastructure and road Safety", Transport and Communications Bulletin for Asia and the Pacific, no. 83, (2013), pp. 19-25.

[5] M. R. Keymanesh, A. A. Nsrollahtabar, R. M. Moafi and B. Naderi, "Identification and Management of Black spots Case Study of Haraz Roads", Journal of Middle East Applied Science and Technology, Issue, [Supplementary part V], vol. 15, no. 4, (2014), pp. 780-785.

[6] A. Kusumawati and Y. D. Wong, "The Application of Empirical Bayes Approach for Identifying and Ranking Hazardous Junctions", Journal of the Eastern Asia Society for Transportation Studies, vol. 8, (2010).

[7] A. Montella, "A Comperative Analysis of Hotspot Identification Methods", Elsevier Accident Analysis and Prevention, vol. 42, (2010), pp. 571-581.

[8] E. F. Saccomanno, R. Grossi, D. Greco and A. Mehmood, "Identifying Blackspots Along Highway SS107in Southern Italy Using Two Models", Journal of Transportation Engineering, vol. 1542, (2001), pp. 515-521.

[9] S. Aliaasghar, A. Esmaeel and P. Neghab Mohammadali, "Identification and Prioritization of Hazardous Road Locations by Segmentation and Data Envelopment Analysis Approach", Promet - Traffic and Transportation, vol. 25, no. 2, (2013), pp. 127-136.

[10] K. Van Raemdonck and C. Macharis, "The road accident analyzer: a tool to identify high risk locations", Journal of Transportation, Safety and Security, vol. 6, (2014), pp. 130-151.

[11] F. Despoina, "Road risk analysis in the section of New National Road Athens-Thessaloniki in the regional Unit of Fthiotida", Thesis submitted for the Diploma of Civil Engineering, Democritus University of Thrace, (2014).

[12] I. Frantzeskakis and I. Gkolias, "Road Safety", Papasotiriou Editions, (1994).

[13] G. Geurts and G. Wets, "Black spot analysis: Literature review", Belgium, Policy Research Centre for Traffic Safety and Increasing Mobility, RA-2003-07, (2003), 30p.

[14] Institute of Transport Economics. State-of-the-art approaches to road accident black spot management and safety analysis of road networks. Norwegian Centre for Transport Studies, (2007).

[15] K. Stefanos, "Ways of identification black spots and implementation of them in New National Road Athens-Lamia", Thesis submitted for the Diploma of Civil Engineering, Democritus University of Thrace, (2014).

[16] L. Meuleners and M. Fraser, "Review of the WA state black spot program: a literature review of Australian and international black spot programs", Centre for Population Health Research, Curtin University of Technology, (2008).

[17] C. J. Mollet and C. J. Bester, "An Introductory Guideline for the Use of Bayesian Statistical Methods in the Analysis of Road Traffic Accident Data", South African Transport Conference: Action in Transport for the New Millennium, (2000) July 17-20.

[18] OECD. Road safety annual report. Organization for Economic Co-operation and Development, Paris, France. PIARC (World Road Association) (2003). Road safety manual, PIARC, Paris, France, (2014).

[19] PIARC Road Safety Manual, (2003).

[20] Republic of Turkey. Black spot manual. General Directorate of Highways, Traffic Safety Project, (2001).

[21] RoadERANet. Road Infrastructure Safety Management Evaluation Tools (RISMET). Guidelines for development and application of Evaluation tools for road infrastructure safety management in Europe, (2011).

[22] G. Geurts, G. Wets, T. Brijs, D. Karlis and K. Vanhoof, "Identification, and ranking of black spots: sensitivity analysis", Transportation Research Board, Annual Meeting, Washington D.C., 11-15 January, (2004).

[23] S. Ladi, D. C. Wijeyesekera, A. Brimicombe and Y. Li, "Road Traffic Accident Hotspot Identification Using Modified Voronoi Process", Proceedings of Advances in Computing and Technology, (AC\&T) The School of Computing and Technology, 4th Annual Conference, University of East London, (2009), pp. 189-198.

[24] S. Mungnimit, K. Jierranaitanakit and S. Chayanan, "Sequential Data Analysis for Black Spot Identification", Proceeding of the 4th IRTAD Conference, Road Safety Data: Collection and Analysis for Target Setting and Monitoring Performances and Progress, Seoul, (2009) September 16-17, pp. 219222.

[25] X. Panagolia, A. Theofilatos and G. Yannis, "A review of the impact of traffic volume on road accidents", 6th Pan-hellenic Conference on Road Safety, Athens, Greece, (2015) March 12-13.

[26] G. Zovak, D. Brcic and Z. Šaric, "Analysis of road black spots identification method in Republic of Croatia", Proceedings of 9th International Conference of Road Safety in Local Community, Zajecar, Serbia, (2014) April 9-11, pp. 267-271.

[27] Allianz. Traffic accidents is number one worldwide cause of death among youngs. Allianz Ltd. https://www.allianz.com/en/press/news/commitment/community/141029-allianz-on-road-safety.html (2014).

[28] Hellenic Police: http://www.astynomia.gr/index.php?option=ozo_content\&perform=view\&id $=44440 \&$ Itemid $=86 \&$ lang $=\&$ lang $=($ 2014 $)$. 
[29] WHO. Health statistics and information systems - Projections of mortality and causes of death, 2015 and 2030. World Health Organization http://www.who.int/healthinfo/global_b urden_disease/projections/en/, (2013).

[30] WHO. World report on road traffic injury prevention'. Geneva, Switzerland, World Health Organisation, (2014).

\section{Authors}

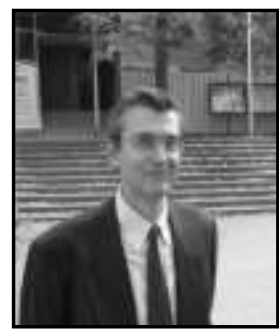

Alexandros Kokkalis, MSc \& PhD civil eng., Aristotle Univ. Thessaloniki, MSc highway \& transport eng., Univ. Birmingham. Worked as a professional highway engineer during 1985-95. In the last 20 years, he is assistant/associate professor in the field of highway \& transport engineering, Democretus Univ. of Thrace. He also works as a consultant in Egnatia Odos SA and, at project level, with various companies. He is the (co)author of 80 scientific papers, mostly on highway design and traffic safety.

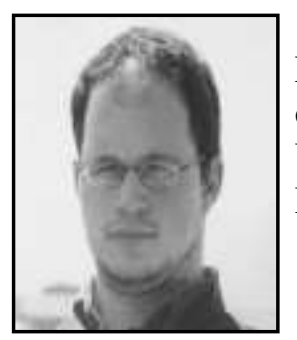

Fanourios Kalpakis is both Civil and Mechanical Engineering (Production \& Management Engineering). He also obtained a Master degree in transportation systems by Aristotle University of Thessaloniki. Currently, he is a $\mathrm{PhD}$ candidate in Democritus University of Thrace, in the realms of road safety. 
International Journal of Transportation

Vol.5, No.2 (2017) 